\title{
Expert System to Diagnose Bonsai Plant Pests with Certainty Factor Method
}

\author{
Michael $^{1}$, Sulindawaty ${ }^{2}$ \\ 1,2Informatics Engineering, STMIK Pelita Nusantara, Sumatera Utara, Indonesia
}

\section{Article Info}

\section{Article history:}

Received Dec 09, 2021

Revised Dec 20, 2021

Accepted Jan 11, 2022

\section{Keywords:}

Expert System;

Diseases and Pests;

Bonsai;

Certainty Factor

\begin{abstract}
Bonsai ornamental plants are dwarf plants which are generally planted in shallow pots. The main element in bonsai is harmony between pots and plants, in addition to harmony between pots and plants there are also other elements such as trunk size, tree height, root distribution, twigs, and leaf size as well as diseases and pests that attack the bonsai plants need to be considered. The difficulty of the community in conducting consultations and the unavailability of funds and time, so that the community has never conducted consultations about diseases and pests that attack their bonsai plants to experts or plant extension workers from the relevant agencies. Therefore, it is necessary to take action to anticipate the increasing number of bonsai farmers who do not consult on diseases and pests of bonsai plants. This is due to the delay in the diagnosis of the disease. The unavailability of experts or plant extension workers who are close, the community does not have time to conduct consultations and requires money. An expert system is a computer-based system that uses knowledge, facts, and techniques and reasoning in solving problems that can usually only be solved by an expert in the field. The Certainty Factor method is efficient enough to be used in diagnosing the diseases and pests of the bonsai plant. This system can provide early diagnosis of diseases and pests on the bonsai plant based on the symptoms and intensity of the symptoms that are visible from the outside. Users only need to enter the Web to take the first step in solving bonsai plant diseases and pests and choose the symptoms of the disease they are experiencing without having to ask an expert directly. This system is made web-based with PHP programming language and MySQL database.
\end{abstract}

This is an open access article under the CC BY-NC license.

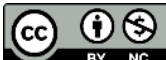

\section{Corresponding Author:}

Michael,

Informatics engineering,

STMIK Pelita Nusantara, Sumatera Utara, Indonesia

Jl.Iskandar Muda no.1 Medan,Sumatera Utara,Indonesia

E-mail: michaelsimorangkir332@gmail.com

\section{Introduction}

The art of Bonsai plants in Indonesia is one of the works of art by flower farmers and is quite well developed in Indonesia. This is because the State of Indonesia has good natural fertility and also a wealth of flora species because Indonesia is located in a tropical area. Indonesia is an archipelagic country and almost every island in Indonesia has a special type of flora, one of which is the Bonsai plant which is a characteristic of the island itself. These types of special flora in Indonesia can be used 
as good Bonsai plant materials, where from these materials the artwork of Bonsai plants in Indonesia was born and developed well until now.

Bonsai plants are an artistic effort to dwarf plants as a representation of the beauty of the natural panorama which is full of various kinds of trees, both in shape, type, and color. In essence, the art of bonsai is imitating or making imitations of plant forms that exist in the wild whose growth languishes due to the ferocity of nature (Lembahmata, 2011). In bonsai farming, there are various kinds of diseases and pests that attack the bonsai plant, for example: aphids. In the spring aphids on Bonsai plants can become a real problem, especially on newly emerging young/mample leaves (Ipnuwati \& Aditama, 2020). Many Bonsai plant farmers do not know the diseases and pests that have attacked their Bonsai plants, therefore we need a system that is able to diagnose diseases and pests on the Bonsai plant in the form of an expert system by applying the Certainty Factor method.

Previous research entitled Application of Forward Chaining and Certainty Factor Methods for Disease Diagnosis in Bonsai Plants where in this study diagnose bonsai plant diseases using two methods, namely forward chaining and certainty factor, the system was built to determine the symptoms that appear and the test results can provide a diagnosis diseases and pests on bonsai plants based on the symptoms given. However, in this study, the types of diseases and pests that were diagnosed only consisted of aphids, caterpillars, thrips, white hornworms, fungi, red shoots on stems and root tumors. While the types of diseases and pests that attack bonsai plants exceed the types of diseases and pests studied. Then in the study entitled "Expert System Determination of Style on Bonsai Plants Using the Certainty Factor Method", this study was designed to determine the style of bonsai that gives results in the form of pictures and names of bonsai plant styles (Dwilestari \& Nurmiati, 2018). Then in a similar study entitled Expert System for Agribusiness Plant Diagnosis Using the Certainty Factor Method, in this study it was suggested that the certainty factor method is very suitable to be used to diagnose diseases in agribusiness plants because this method can help to overcome uncertainty in decision making and provide a percentage of diagnostic results. . From the results of testing this expert system, obtained the same results with manual calculations using the certainty factor method, so it is concluded that this expert system can be used to diagnose agribusiness plant diseases(Laely, 2020).

Expert systems are also commonly referred to in other words, namely knowledge based systems, a computer application intended to assist decision making or problem solving in specific fields (Rukun \& Hayadi, 2018). An expert system is a part of artificial intelligence that is intended for diagnosing system failures and as a solution to problems(Setiawan, 2017). An Expert System is a knowledge-based program that provides expert quality solutions to problems in a specific domain. Expert System is a computer program that imitates thought processes and expert knowledge in solving a particular problem(Salisah, Lidya, \& Defit, 2015).

This study aims to design and build an expert system for diagnosing Bonsai diseases and pests by applying the certainty factor method, and how to find out the results of the diagnosis and how to analyze the results of applying the certainty factor method to diagnose Bonsai plant diseases and pests.

\section{Method}

\subsection{Cata Collection}

The data in this study were carried out by literature studies and interviews(Makady, de Boer, Hillege, Klungel, \& Goettsch, 2017).

a. Study of Literature

Literature study is looking for theoretical references that are relevant to the cases or problems found according to the research title. These references are obtained from printed and electronic books, journals, research report articles, and searches on sites on the internet.

b. Interviews

One method of data collection is by way of interviews, namely getting information by asking directly to respondents, the respondents referred to in this study are bonsai plant botanists and agricultural extension specialists, especially bonsai plant diseases to obtain data on types of bonsai plant diseases and their symptoms the symptoms. The respondent is Mr. Ir. Ariady Ribawa 
Sari, M.P (Head of Plant Extension) Department of Food Crops and Horticulture Deli Serdang Regency

\subsection{Data Anlysis}

After collecting data and the data that has been collected, the next step is to analyze or process the data that has been previously collected using the certainty method with the aim that the problem formulation can be resolved so that the expert system for diagnosing diseases and pests in bonsai plants can be useful (Juliandi, Manurung, \& Satriawan, 2018),(Situmorang, Muda, Doli, \& Fadli, 2010)

TABLE 1

CHARACTERISTICS OF CERTAINTY FACTOR

\begin{tabular}{lll}
\hline No & \multicolumn{1}{c}{ Characteristics } & \multicolumn{1}{c}{ Score } \\
\hline \multirow{2}{*}{1} & Reach & $0 \leq \mathrm{MB} \leq 1$ \\
& & $0 \leq \mathrm{MD} \leq 1$ \\
& & $-1 \leq \mathrm{CF} \leq 1$ \\
2 & The Hypotesis Must Be True & $\mathrm{MB}=1$ \\
& $\mathrm{P}(\mathrm{H} \mid \mathrm{E})=1$ & $\mathrm{MD}=0$ \\
& & $\mathrm{CF}=1$ \\
3 & The Hypotesys Must Be False & $\mathrm{MD}=0$ \\
& $\mathrm{P}\left(\mathrm{H}^{\prime} \mid \mathrm{E}\right)=1$ & $\mathrm{CF}=-1$ \\
& & $\mathrm{MB}=0$ \\
4 & Lack of Facts $\mathrm{P}(\mathrm{H} \mid \mathrm{E})=\mathrm{P}(\mathrm{H})$ & $\mathrm{MD}=0$ \\
& & $\mathrm{CF}=0$ \\
\hline
\end{tabular}

Some of the rules for using the certainty factor method are as follows:

1) The rule for adding two certainty positive factors is

2) The rules for adding two negative certainty factors are:

$\left(\mathrm{CF}_{\mathrm{c}} \mathrm{CF}_{\mathrm{d}}\right)=\mathrm{CF}_{\mathrm{c}}+\mathrm{CF}_{\mathrm{d}}+\mathrm{CF}_{\mathrm{c}}{ }^{*} \mathrm{CF}_{\mathrm{d}}$

3) The rules for adding more complex positive and negative certainty factors are:

$$
\left(\mathrm{CF}_{\mathrm{e}} \mathrm{CF}_{\mathrm{f}}\right)=\frac{\mathrm{CF}_{\mathrm{e}}+\mathrm{CF}_{\mathrm{f}}}{1-\min \left\{\left|\mathrm{CF}_{\mathrm{e}}\right|,\left|\mathrm{CF}_{\mathrm{n}}\right|\right\}}
$$

These three rules provide an interval scale for the certainty factor. The examples of the application of the certainty factor rules mentioned above are as follows:

a. Examples for Positive Facts

Strong Sugestive (CFa) : 0.7

Sugestive (CFb) : 0.4

Sugestive (CFb) : 0.4

$\mathrm{CF}_{\text {Combine }}(\mathrm{CFa} \mathrm{CFb}) 0.7+0.4(1-0.7)=0.82$

b. Examples for Negative Facts

Strong Suggestive (CFc) : -0.7

Suggestive (CFd) : -0.4

$\mathrm{CF}_{\text {Combine }}(\mathrm{CFC}$ CFd $)=-0.7+-0.4+-0.7 *-0.4=-0.82$

\section{Result and Discussion}

In designing this expert system by taking sources from experts or doctors, books and journals. This web-based design is useful for diagnose bonsai plant pests with certainty factor method type of disease.

a. Type of Disease

TABLE 2

CHARACTERISTICS OF CERTAINTY FACTOR

\begin{tabular}{ccl}
\hline Code & Disease & \multicolumn{1}{c}{ Treatment Solution } \\
\hline P1 & Aphids & $\begin{array}{l}\text { Getting rid of diseased plants for a while, if not too severe can be overcome by } \\
\text { spraying warm water once a week and sprayed with medicine. For example: } \\
\text { water mixed with insecticidal soap which is safe and effective }\end{array}$ \\
P2 & Caterpillar & $\begin{array}{l}\text { Destroy the caterpillars, try to pull out weeds that grow around them so that } \\
\text { pests don't come back or spray insecticides such as Curacron 100 ml and }\end{array}$
\end{tabular}




\begin{tabular}{|c|c|c|c|}
\hline Code & Disease & Treatment Solution & Group \\
\hline P3 & Thrips & $\begin{array}{l}\text { Dursban } 200 \mathrm{EC} \text { ". } \\
\text { Clean the plant with warm water and spray the appropriate medicine once a } \\
\text { week for two weeks. The medicine: Counter Plus } 100 \text { Gram and Larban } \\
550 \mathrm{EC} \text {. }\end{array}$ & Pest \\
\hline P4 & White Whip & $\begin{array}{l}\text { Get rid of the ants that are on the bonsai plant and clean with warm water, } \\
\text { then given the appropriate medicine for white powder disease. For example: } \\
\text { Phefoc HCS and METHA 400EC". }\end{array}$ & Pest \\
\hline P5 & $\begin{array}{l}\text { Red Whip on } \\
\text { the Stem }\end{array}$ & $\begin{array}{l}\text { The bonsai tree is brushed with a toothbrush and sprayed with insecticide. } \\
\text { For example: Ointment Kambiun Bonsai Fungicide, Lime Sulfur } 300 \mathrm{ml} \text { and } \\
\text { Ointment Kambiun Healthy Liquid } 100 \mathrm{ml} \text {. }\end{array}$ & Pest \\
\hline P6 & Aphis & $\begin{array}{l}\text { Control of this pest is very easy, you just need to spray it with high pressure } \\
\text { water so it will fall and die, or you can also use a mild insecticide such as } \\
\text { Curacron 500EC, Decis } 2.5 \mathrm{EC} \text {, and Confidor } 200 \mathrm{SL} \text {. }\end{array}$ & Pest \\
\hline P7 & $\begin{array}{l}\text { Shell or } \\
\text { Shield Lice }\end{array}$ & $\begin{array}{l}\text { This pest control is recommended by selective use of synthetic pesticides. In } \\
\text { addition, the application of plant-based pesticides (non-synthetic) can also be } \\
\text { carried out in the form of extracts of keben seeds, Lamda Sihalotrin and } \\
\text { Triazofos } 0.5 \% \text {. }\end{array}$ & Pest \\
\hline P8 & Snail & $\begin{array}{l}\text { Use special toxic pellets for snails or by fishing for their arrival by placing } \\
\text { cassava or sticky rice on a bonsai tree pot at night, then the next morning the } \\
\text { snails around the tapai are killed, or using molluscicides with active } \\
\text { ingredients fentin acetatefentin acetate and or metaldehyde (metadehyde). }\end{array}$ & Pest \\
\hline P9 & Mold & $\begin{array}{l}\text { Remove the damaged plant parts, then spray with warm water or treat with } \\
\text { insecticides. For example: Dithane M45 } 200 \text { Grams. }\end{array}$ & Disease \\
\hline P10 & Root Tumor & $\begin{array}{l}\text { The solution is to replace the old soil with new soil, or apply a fungicide to the } \\
\text { trunk of the bonsai tree. For example: Calixin, Fylomax or bordo porridge by } \\
\text { using a brush up to } 30 \mathrm{~cm} \text { upwards to the bottom of the affected part of the } \\
\text { root tumor, and if the attack is advanced, then exfoliate the rotten root bark } \\
\text { and then lubricate it with Calixin RM to taste. }\end{array}$ & Disease \\
\hline P11 & $\begin{array}{l}\text { Powdery } \\
\text { Mildew }\end{array}$ & $\begin{array}{l}\text { The treatment solution is to use a wettable sulfur-based fungicide }(3 \mathrm{G} / \mathrm{L}) \\
\text { hexaconazole, tripumizole, microbutanil (total } 2 \mathrm{ml} / \mathrm{L} \text { ). }\end{array}$ & Disease \\
\hline
\end{tabular}

b. Symptoms

TABLE 3

SYMPTOMS

\begin{tabular}{|c|c|}
\hline Code & Symptoms \\
\hline G001 & Dried or curled leaves \\
\hline G002 & Brown leaves \\
\hline G003 & The leaves and stems are weak \\
\hline G004 & No new leaves grow \\
\hline G005 & The leaves have holes \\
\hline G006 & There is caterpillar droppings on the surface of the leaves or stems \\
\hline G007 & The buds fail to become flowers and fall \\
\hline G008 & The spots on the leaves then blister and fall off \\
\hline G009 & Upper and lower leaf surfaces turn black, Brown leaves \\
\hline G010 & Surrounded by ants, then there are fly eggs on the underside of the leaves \\
\hline G011 & There is a beast in the bark of the stem \\
\hline G012 & The tops of the leaves become wrinkled, curled and curled \\
\hline G013 & In heavy attacks it causes stunted plant growth, wilts and even dies \\
\hline G014 & Plants do not grow normally, causing stunted plants and the leaves become a mosaic \\
\hline G015 & In conditions of severe attack, this pest colony can abort the leaves of the bonsai plant as a whole \\
\hline G016 & Bonsai plant leaves wither \\
\hline G017 & In the next attack the leaves and flowers fall without remaining \\
\hline G018 & Attacking the stems, twigs or leaves of newly seeded bonsai \\
\hline G019 & The green color of the affected part will turn yellow \\
\hline G020 & $\begin{array}{l}\text { Indirect damage is the emergence of sooty mold (capnodium) on the surface of plants that are } \\
\text { attacked by shell lice }\end{array}$ \\
\hline G021 & These pests often leave irregular and often large holes in the leaves \\
\hline G022 & $\begin{array}{l}\text { The presence of silver-colored slime spots found on the leaves of bonsai plants and the surface of the } \\
\text { soil in pots }\end{array}$ \\
\hline G023 & Young bonsai plant seeds are very liked and eaten by these snail pests \\
\hline G024 & Withered Plant \\
\hline G025 & Crown fall \\
\hline G026 & Curly leaf shoots \\
\hline G027 & Stalks and leaves turn yellow and tear rot \\
\hline G028 & Stems and roots rot \\
\hline
\end{tabular}




\begin{tabular}{ll}
\hline Code & \multicolumn{1}{c}{ Symptoms } \\
\hline G029 & If watered, it doesn't run out quickly \\
G030 & New leaves don't grow and the shoots wilt quickly \\
G031 & At first, yellow spots appear on the upper side of the leaves \\
G032 & $\begin{array}{l}\text { At a later stage, the white powdery layer turns gray and covers the entire surface of the leaves and } \\
\text { stems of the bonsai }\end{array}$ \\
G033 & As the disease progresses, the infected part shrivels up and the leaves fall off and die \\
\hline
\end{tabular}

c. Disease Probability Score

TABLE 4

INTERPRETATION OF CERTAINTY FACTOR WEIGHT VALUE MB

\begin{tabular}{lc}
\hline \multicolumn{1}{c}{ Certainty Term } & MB Value \\
\hline Unknow & 0 \\
Maybe Yes & $0.40-0.74$ \\
Probably Yes & $0.75-0.89$ \\
Almost Certainty Yes & $0.90-0.99$ \\
Definetely Yes & 1.0 \\
\hline
\end{tabular}

TABLE 5

INTERPRETATION OF CERTAINTY FACTOR WEIGHT VALUE MB

\begin{tabular}{lc}
\hline \multicolumn{1}{c}{ Certainty Term } & MD Value \\
\hline Definetely Not & $0-0.02$ \\
Almost Certainty Not & $0.03-0.05$ \\
Probably Not & $0.06-0.08$ \\
Maybe Not & $0.09-0.10$ \\
\hline
\end{tabular}

d. Knowledge Base

TABLE 6

RULE S

\begin{tabular}{cl}
\hline & \multicolumn{2}{c}{ Rules } \\
\hline Rule 1 & IF G001 AND G002 AND G003 AND THEN P1 \\
Rule 2 & IF G005 AND G006 THEN P2 \\
Rule 3 & IF G007 AND G008 THEN P3 \\
Rule 4 & IF G009 AND G010 THEN P4 \\
Rule 5 & IF G011 THEN P5 \\
Rule 6 & IF G012 AND G013 AND G014 AND G015 THEN P6 \\
Rule 7 & IF G016 AND G017 AND G018 AND G019 AND G020 THEN P7 \\
Rule 8 & IF G021 AND G022 AND G023 THEN P8 \\
Rule 9 & IF G024 AND G025 AND G026 AND G027 AND G028 THEN P9 \\
Rule 10 & IF G029 AND G030 THEN P10 \\
Rule 11 & IF G031 AND G032 AND G033 THEN P11 \\
\hline
\end{tabular}

e. Determining MB and MD Values

TABLE 7

MB AND MD PROBABILITY SCORE FOR EACH SYMPTOM

\begin{tabular}{|c|c|c|c|c|}
\hline Code & Symptoms & MB & MD & $\begin{array}{l}\text { CF=MB- } \\
\text { MD }\end{array}$ \\
\hline G001 & Dried or curled leaves & 1.00 & 0.00 & 1.00 \\
\hline G002 & Brown leaves & 0.93 & 0.06 & 0.87 \\
\hline G003 & The leaves and stems are weak & 0.90 & 0.04 & 0.86 \\
\hline G004 & No new leaves grow & 0.70 & 0.05 & 0.65 \\
\hline G005 & The leaves have holes & 1.00 & 0.00 & 1.00 \\
\hline G006 & There is caterpillar droppings on the surface of the leaves or stems & 0.93 & 0.05 & 0.88 \\
\hline G007 & The buds fail to become flowers and fall & 1.00 & 0.05 & 0.95 \\
\hline G008 & The spots on the leaves then blister and fall off & 0.90 & 0.02 & 0.88 \\
\hline G009 & Upper and lower leaf surfaces turn black, Brown leaves & 1.00 & 0.00 & 1.00 \\
\hline G010 & Surrounded by ants, then there are fly eggs on the underside of the leaves & 0.95 & 0.04 & 0.91 \\
\hline
\end{tabular}




\begin{tabular}{|c|c|c|c|c|}
\hline Code & Symptoms & MB & MD & $\begin{array}{l}\text { CF=MB- } \\
\text { MD }\end{array}$ \\
\hline G011 & There is a beast in the bark of the stem & 1.00 & 0.06 & 0.94 \\
\hline G012 & The tops of the leaves become wrinkled, curled and curled & 0.95 & 0.05 & 0.90 \\
\hline G013 & In heavy attacks it causes stunted plant growth, wilts and even dies & 0.76 & 0.06 & 0.70 \\
\hline G014 & $\begin{array}{l}\text { Plants do not grow normally, causing stunted plants and the leaves } \\
\text { become a mosaic }\end{array}$ & 0.94 & 0.05 & 0.89 \\
\hline G015 & $\begin{array}{l}\text { In conditions of severe attack, this pest colony can abort the leaves of the } \\
\text { bonsai plant as a whole }\end{array}$ & 0.65 & 0.06 & 0.59 \\
\hline G016 & Bonsai plant leaves wither & 1.00 & 0.00 & 1.00 \\
\hline G017 & In the next attack the leaves and flowers fall without remaining & 0.94 & 0.02 & 0.92 \\
\hline G018 & Attacking the stems, twigs or leaves of newly seeded bonsai & 0.75 & 0.06 & 0.69 \\
\hline G019 & The green color of the affected part will turn yellow & 0.92 & 0.03 & 0.89 \\
\hline G020 & $\begin{array}{l}\text { Indirect damage is the emergence of sooty mold (capnodium) on the } \\
\text { surface of plants that are attacked by shell lice }\end{array}$ & 0.70 & 0.04 & 0.66 \\
\hline G021 & These pests often leave irregular and often large holes in the leaves & 0.95 & 0.03 & 0.92 \\
\hline G022 & $\begin{array}{l}\text { The presence of silver-colored slime spots found on the leaves of bonsai } \\
\text { plants and the surface of the soil in pots }\end{array}$ & 0.84 & 0.05 & 0.79 \\
\hline G023 & Young bonsai plant seeds are very liked and eaten by these snail pests & 0.93 & 0.02 & 0.91 \\
\hline G024 & Withered Plant & 0.90 & 0.02 & 0.88 \\
\hline G025 & Crown fall & 0.80 & 0.03 & 0.77 \\
\hline G026 & Curly leaf shoots & 0.60 & 0.05 & 0.55 \\
\hline G027 & Stalks and leaves turn yellow and tear rot & 0.89 & 0.04 & 0.85 \\
\hline G028 & Stems and roots rot & 0.95 & 0.02 & 0.93 \\
\hline G029 & If watered, it doesn't run out quickly & 1.00 & 0.02 & 0.98 \\
\hline G030 & New leaves don't grow and the shoots wilt quickly & 0.87 & 0.05 & 0.82 \\
\hline G031 & At first, yellow spots appear on the upper side of the leaves & 1.00 & 0.00 & 1.00 \\
\hline G032 & $\begin{array}{l}\text { At a later stage, the white powdery layer turns gray and covers the entire } \\
\text { surface of the leaves and stems of the bonsai }\end{array}$ & 0.97 & 0.04 & 0.93 \\
\hline G033 & $\begin{array}{l}\text { As the disease progresses, the infected part shrivels up and the leaves fall } \\
\text { off and die }\end{array}$ & 0.83 & 0.05 & 0.78 \\
\hline
\end{tabular}

f. Case Study Examples

TABLE 8

MB AND MD PROBABILITY SCORE FOR EACH SYMPTOM

\begin{tabular}{clcc}
\hline Code & \multicolumn{1}{c}{ Symptom } & User Answer & Score \\
\hline G001 & Dried or curled leaves & Definetely Yes & 1.0 \\
G002 & Brown leaves & Definetely Yes & 1.0 \\
G003 & The leaves and stems are weak & Probably Yes & 0.8 \\
& There is caterpillar droppings on the surface of the & Maybe Yes & 0.6 \\
G006 & leaves or stems & Almost Certainty Yes & 0.9 \\
G007 & The buds fail to become flowers and fall & Definetely Yes & 1.0 \\
G008 & The spots on the leaves then blister and fall off & Maybe Yes & 0.6 \\
G011 & There is a beast in the bark of the stem &
\end{tabular}

If viewed from several disease symptoms that have been selected by the user, the symptoms of the disease can be classified based on the type of disease below:

1) G001, G002, and G003 belong to diseases and pests: P1

2) G006, which belongs to the types of diseases and pests: P2

3) G007 and G008, which belong to the types of diseases and pests: P3

4) G011, which belongs to the types of diseases and pests: P5

The next step is to calculate the expert CF (Certainty Factor) value for each disease symptom selected by the user: 
a. Diseases and Pests : P1

1) G001: Dried or curled leaves $\mathrm{CF}(\mathrm{H}, \mathrm{E})=\mathrm{MB}-\mathrm{MD}=1.0-0.0=1$

2) G002 : Browns Leaves $\mathrm{CF}(\mathrm{H}, \mathrm{E})=\mathrm{MB}-\mathrm{MD}=0.93-0.06=0.87$

3) G003: The Leaves and Stems are weak $\mathrm{CF}(\mathrm{H}, \mathrm{E})=\mathrm{MB}-\mathrm{MD}=0.90-0.04=0.86$

After knowing the expert CF value for each symptom, the CF value for each symptom is calculated by multiplying the expert $\mathrm{CF}$ with the User $\mathrm{CF}$ :

1) G001: Dried or curled leaves $\mathrm{CF}(\mathrm{H}, \mathrm{e})=\mathrm{CF}_{\mathrm{user}} * \mathrm{CF}_{\text {pakar }}=1.0 * 1=1$

2) G002: Browns Leaves $\mathrm{CF}(\mathrm{H}, \mathrm{e})=\mathrm{CF}_{\mathrm{user}} * \mathrm{CF}_{\text {pakar }}=1.0 * 0.87=0.87$

3) G003: The Leaves and Stems are Weak $\mathrm{CF}(\mathrm{H}, \mathrm{e})=\mathrm{CF}_{\text {user }} * \mathrm{CF}_{\text {pakar }}=0.8 * 0.86=0.69$

Then combine the $\mathrm{CF}$ values of each symptom:

$$
\begin{aligned}
& \mathrm{CF}_{\text {combine1 }} \mathrm{CF}(\mathrm{H}, \mathrm{E})_{1,2}=\mathrm{CF}_{\mathrm{G} 001}+\mathrm{CFG}_{002} *\left(1-\mathrm{CF}_{\mathrm{G} 001}\right)=1+0.87 *(1-1)=\mathbf{1} \\
& \mathrm{CF}_{\text {combine2 }} \mathrm{CF}(\mathrm{H}, \mathrm{E})_{\text {old }, 3}=\mathrm{CF}_{\text {old }}+\mathrm{CF}_{\mathrm{G} 003} *\left(1-\mathrm{CF}_{\text {old }}\right)=1+0.69 *(1-1)=\mathbf{1}
\end{aligned}
$$

So, when used as a percentage, then:

Disease: P1 = 1* $100=100 \%$. Thus, from the three symptoms selected by the user from the disease: Aphids on Bonsai plants, the conclusion based on the calculation of the diagnosis experienced is P1 with a confidence level of $100 \%$.

b. Disease and Pests : P2

1) G006: There is Caterpillar droppings on the surface of the leaves or stems $\mathrm{CF}(\mathrm{H}, \mathrm{E})=\mathrm{MB}-\mathrm{MD}=0.93-0.05=0.88$

Since the type of symptom selected by the user is only one type in P2 disease, then after knowing the expert CF value of the symptom selected by the user the CF value of the symptom is calculated by multiplying the expert CF by the User CF:

2) G006: There is Caterpillar droppings on the surface of the leaves or stems $\mathrm{CF}(\mathrm{H}, \mathrm{e})=\mathrm{CF}_{\text {user }} * \mathrm{CF}_{\text {pakar }}=0.6 * 0.88=0.53$

If used as a percentage then:

Disease P2 $=0.53 * 100=53 \%$

Since only one symptom was selected for P2 disease, the conclusion based on the calculation of the diagnosis experienced by bonsai plants was P2 with a confidence level of $53 \%$.

c. Disease and Pests : P3

1) G007: The buds fail to become flowers and fall $\mathrm{CF}(\mathrm{H}, \mathrm{E})=\mathrm{MB}-\mathrm{MD}=1-0.05=0.94$

2) G008: The spots on the leaves then blister and fall off $\mathrm{CF}(\mathrm{H}, \mathrm{E})=\mathrm{MB}-\mathrm{MD}=0.9-0.02=0.88$

Since the symptom selected by the user is more than one symptom, after knowing the expert CF value for each symptom, the CF value for each symptom is calculated by multiplying $\mathrm{CF}_{\text {pakar }}$ with $\mathrm{CF}_{\text {user }}$ :

1) G007: The buds fail to become flowers and fall $\mathrm{CF}(\mathrm{H}, \mathrm{e})=$ CFuser $^{*}$ CFpakar $=0.9 * 0.94=0.85$ G008: The spots on the leaves then blister and fall off

2) $\mathrm{CF}(\mathrm{H}, \mathrm{e})=\mathrm{CFuser} *$ CFpakar $=1.0 * 0.88=0.88$ Then combine the $\mathrm{CF}$ values of each symptom:

3) CFcombine1 CF(H,E)1,2 = CFG007 + CFG008 * $(1-\mathrm{CFG007)}=0.85+0.88 *(1-0.85)=0.98$

d. So, when used as a percentage, then:

Diseases and pests: P3 $=0.98 * 100=98 \%$. 
Thus, from the two symptoms selected by the user from the disease: P3 on Bonsai plants, the conclusion based on the calculation of the diagnosis experienced by bonsai plants is P3 with a confidence level of $98 \%$

\section{Conclusion}

An expert system using the certainty factor method can be used to determine the value of the confidence factor regarding the attack of diseases and pests on bonsai plants based on the symptoms of diseases and pests that have been determined. By building this expert system application, it can produce good diagnostic results, as evidenced by the results of the application of the certainty factor method in accordance with the certainty factor design and the rule base that has been built. So that the application can provide information on the results of the analysis and the results of the calculation of the certainty factor method with an accuracy of up to $90 \%$ compared to the results of the analysis of expert examinations or bonsai plant extensionists.

\section{References}

Dwilestari, S., \& Nurmiati, S. (2018). Sistem Pakar Penentuan Style Pada Tanaman Bonsai Menggunakan Metode Certainty Factor. Sainstech: Jurnal Penelitian Dan Pengkajian Sains Dan Teknologi, 28(2).

Halim, S. (2015). Rancang Bangun Sistem Pakar Mendeteksi Resiko Osteoporosis dan Osteoarthritis dengan Metode Certainty Factor Berbasis Android. Universitas Multimedia Nusantara.

Ipnuwati, S., \& Aditama, K. (2020). Penerapan Metode Technique For Others Reference By Similarity To Ideal Solution (Topsis) Dalam Pemilihan Tanaman Bonsai Terbaik. Explore: Jurnal Sistem Informasi Dan Telematika (Telekomunikasi, Multimedia Dan Informatika), 11(1), 36-44.

Juliandi, A., Manurung, S., \& Satriawan, B. (2018). Mengolah data penelitian bisnis dengan SPSS. Lembaga Penelitian dan Penulisan Ilmiah AQLI.

Laely, M. (2020). SISTEM PAKAR DIAGNOSIS PENYAKIT TANAMAN CABAI DENGAN METODE FORWARD CHAINING DAN DEMPSTERSHAFER. Publikasi Tugas Akhir S-1 PSTI FT-UNRAM.

Lembahmata, P. (2011). Bonsai: hikayat satu keluarga Cina Benteng. Gramedia Pustaka Utama.

Makady, A., de Boer, A., Hillege, H., Klungel, O., \& Goettsch, W. (2017). What is real-world data? A review of definitions based on literature and stakeholder interviews. Value in Health, 20(7), 858-865.

Nansia, O., \& Sinag, B. (2019). SISTEM PAKAR MENDIAGNOSA PENYAKIT PADA AYAM TERNAK MENGGUNAKAN METODE CERTAINTY FAKTOR. Journal Of Informatic Pelita Nusantara, 4(2), 14-18.

Rukun, K., \& Hayadi, B. H. (2018). Sistem Informasi Berbasis Expert System. Deepublish.

Salisah, F. N., Lidya, L., \& Defit, S. (2015). Sistem Pakar Penentuan Bakat Anak Dengan Menggunakan Metode Forward Chaining. Jurnal Ilmiah Rekayasa Dan Manajemen Sistem Informasi, 1(1), 62-66.

Setiawan, A. (2017). ANALISA DAN PERANCANGAN SISTEM PAKAR MENDIAGNOSA PENYAKIT GINJAL DENGAN MENGGUNAKAN METODE CERTAINTY FACTOR. Seminar Nasional Informatika (SNIf), 1(1), 683-689.

Situmorang, S. H., Muda, I., Doli, M., \& Fadli, F. S. (2010). Analisis data untuk riset manajemen dan bisnis. USUpress. 